Published in final edited form as:

Anal Chem. 2017 December 19; 89(24): 13039-13043. doi:10.1021/acs.analchem.7b03979.

\title{
Remote Activation of a Nanopore for High-Performance Genetic Detection Using a pH Taxis-Mimicking Mechanism
}

\author{
Yong Wang ${ }^{*}, \dagger$, Kai Tian ${ }^{\ddagger}$, Xiao Du ${ }^{\ddagger}$, Rui-Cheng Shi ${ }^{\ddagger}$, and Li-Qun Gu* ${ }^{*}, \ddagger$ \\ †Virginia G. Piper Biodesign Center for Personalized Diagnostics, The Biodesign Institute, Arizona \\ State University, Tempe, Arizona 85287, United States \\ FDepartment of Bioengineering and Dalton Cardiovascular Research Center, University of \\ Missouri, Columbia, Missouri 65211, United States
}

\begin{abstract}
Aerolysin protein pore has been widely used for sensing peptides and proteins. However, only a few groups explored this nanopore for nucleic acids detection. The challenge is the extremely low capture efficiency for nucleic acids (>10 bases), which severely lowers the sensitivity of an aerolysin-based genetic biosensor. Here we reported a simple and easy-to-operate approach to noncovalently transform aerolysin into a highly nucleic acids-sensitive nanopore. Through a remote $\mathrm{pH}$-modulation mechanism, we simply lower the $\mathrm{pH}$ on one side of the pore, then aerolysin is immediately "activated" and enabled to capture target DNA/RNA efficiently from the opposite side of the pore. This mechanism also decelerates DNA translocation, a desired property for sequencing and gene detection, allowing temporal separation of DNAs in different lengths. This method provides insight into the nanopore engineering for biosensing, making aerolysin applicable in genetic and epigenetic detections of long nucleic acids.
\end{abstract}

\section{Graphical Abstract}

\footnotetext{
*Corresponding Authors: ywan1012@asu.edu.,gul@missouri.edu.

Supporting Information

The Supporting Information is available free of charge on the ACS Publications website at DOI: 10.1021/acs.anal-chem.7b03979. Sequences, $\mathrm{p} K_{\mathrm{a}}, I-t$ scattering plot, $f-[\mathrm{DNA}]$ and $k_{\mathrm{O}}-$ [DNA] curves, $I-\mathrm{pH}$ curve, RNA translocation, ion selectivity measurement, PCR result, $\tau$ histograms, DNA charge evaluation, and supplementary methods (PDF)

The authors declare no competing financial interest.
} 


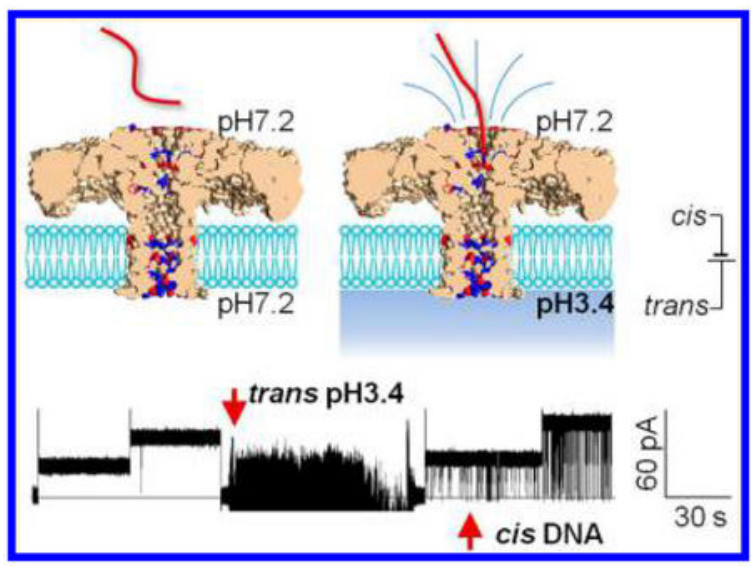

Nanopore is a new-generation biosensing technology. Its single-molecule sensitivity enables a variety of biomedical applications, ' from gene sequencing, to genetic, epigenetic, ${ }^{-}$and proteomic detections. ${ }^{-}$Recently, aerolysin has been emerged as a new nanopore system for sensing peptides,' proteins, ${ }^{-}$polysaccharides, and biological relevant polymers. However, in contrast to most protein pores (e.g., Phi29, MspA, $a$-hemolysin, and SP1), there are much fewer studies on aerolysin-based nucleic acid detections. Representative studies include Pastoriza-Gallego et al. and Payet et al. investigated the translocation of DNA through the aerolysin pore; and Long's group discovered that aerolysin's conductance variation caused by short oligonucleo-tides ( $<10 \mathrm{nts})$ translocation can be used to discriminate the DNA length at the single nucleotide resolution. By now, a main challenge confronted by aerolysin for genetic detection is the extremely low capture efficiency for target nucleic acids (>10 nts). For example, previous studies' have shown that DNA cannot be captured by aerolysin at voltage $<100 \mathrm{mV}$, and DNA translocation rate at voltage $>100 \mathrm{mV}$ is much ( ten fold) lower compared with the widely applied $a$-hemolysin pore. Such low capture efficiency is impractical for nucleic acids detection, thus lowering the enthusiasm for developing aerolysin-based genetic biosensor. In this letter, we present an interesting noncovalent approach to transforming aerolysin into a highly nucleic acids-sensitive nanopore through a remote $\mathrm{pH}$ modulation mechanism. The "activated" aerolysin can not only efficiently capture gene fragments but also decelerate nucleic acids translocation through the nanopore. Both properties are required for sequencing and precise genetic detection.

As shown in Figure 1a, we formed single aerolysin pores from the cis side of the lipid bilayer and presented target DNA D16 (16-nt, Table S1) in the cis solution. A positive voltage $(+40 \mathrm{mV}$ and $+80 \mathrm{mV})$ was applied from the trans compartment, with cis grounded, to drive cis DNA toward the pore. The current trace in Figure 1a shows that when both cis and trans solutions were neutral, the nanopore conductance was not affected by D16, indicating that cis DNA cannot access the aerolysin pore. Strikingly, when lowering $\mathrm{pH}$ of the trans solution to 3.4 while keeping the cis solution (where DNA was presented) neutral, we immediately observed a large number of current blockades that reduced the current from $I_{0}$ of the empty pore to $I$ with $I / I_{0}=4.3 \%$ (Figure $\mathrm{S} 1$ ). The block frequency increased in proportion to the cis DNA concentration (Figure S2). Without DNA, aerolysin alone in this 
$\mathrm{pH}$ gradient did not generate blocks (Figure S3). These findings together suggest that the blockades appeared at low trans $\mathrm{pH}$ are produced by capturing DNA from the cis entrance.

This $\mathrm{pH}$ effect on DNA capture also applied to DNA in the trans solution (Figure S4). Trans D16 did not affect the pore conductance in neutral solutions on both sides, but produced many blockades as the cis $\mathrm{pH}$ was lowered to 2.6 while the trans $\mathrm{pH}$ (where DNA was presented) remained neutral, suggesting that low cis $\mathrm{pH}$ enables DNA capture from the trans entrance. We also found that an RNA fragment can also be captured from one side (cis) by lowing $\mathrm{pH}$ of the opposite side (trans) (Figure S5). Overall, we conclude that, by increasing the acidity on one side, aerolysin can be remotely "activated" and enabled to capture nucleic acids from the opposite side.

Figure $1 \mathrm{~b}$ shows that for all trans $\mathrm{pH}$ tested, the cis DNA capture rate $\left(k_{\mathrm{on}}\right)$ can be enhanced by the voltage. For example, $k_{\text {on }}$ for trans $\mathrm{pH} 3.4$ was increased by over 10 -fold from 0.21 $\pm 0.03 \mu \mathrm{M}^{-1} \mathrm{~s}^{-1}$ to $2.8 \pm 0.4 \mu \mathrm{M}^{-1} \mathrm{~s}^{-1}$ as voltage increased from $+20 \mathrm{mV}$ to $+80 \mathrm{mV}$. This capture efficiency is superior to that of the $a$-hemolysin pore, which is at the $1 \mu \mathrm{M}^{-1} \mathrm{~s}^{-1}$ level at $+100 \mathrm{mV}$ and close to zero at $+80 \mathrm{mV}$. Studying the voltage-dependence of the capture rate can help to understand the nature of the capture procedure. In a capture event, a DNA molecule first migrates from the bulk solution to the pore opening. This is a diffusive step biased by an electric field outside the pore entrance. ${ }^{-}$It is characterized by a linear $k_{\mathrm{on}}$ -V relation." on Next, the DNA is threaded into the pore for translocation, a step that needs to overcome an energy barrier due to the nanopore confinement of DNA end and/or DNA -pore interactions." This barrier-limited capture allows $k_{\mathrm{On}}$ to be exponentially changed with the voltage $\left(k_{\mathrm{on}} \sim \exp (\mathrm{V})\right)$." The DNA capture by aerolysin can be considered as both voltage-biased diffusion-limited and barrier-limited procedures, but diffusion plays a more dominative role, as shown by better linear fitting of the $k_{\mathrm{on}}-\mathrm{V}$ curves as trans $\mathrm{pH}$ decreases (section S1 in the Supporting Information). This implies that lowering trans $\mathrm{pH}$ can decrease the barrier for capturing DNA from the cis entrance.

Decelerated translocation of nucleic acids through the nanopore is a desirable property for sequencing and high-performance genetic detection. This can be achieved by lowering the driving voltage. However, low voltage heavily reduces DNA capture efficiency. Here we found that "activated" aerolysin can prominently decelerate DNA translocation while maintaining high capture efficiency at low voltage (Figure 1a up-right traces and Figure 1c). The DNA block duration $(\tau)$ varied from 0.83 to $40 \mathrm{~ms}$ at voltage between +10 and $\sim+80$ $\mathrm{mV}$ and trans $\mathrm{pH} 3.4-2.1$. This time scale is longer than that for DNA translocation in $a$ -hemolysin $(\sim 100 \mu \mathrm{s})$ by 2 or 3 orders of magnitude. For trans $\mathrm{pH} 3.4$, we observed a hillshaped $\tau-\mathrm{V}$ curve, which suggests that DNA translocates through the pore above the peak voltage ( +30 to $\sim+40 \mathrm{mV}$ ) but returns to the cis solution at smaller voltages. For trans $\mathrm{pH} 2.6$ and 2.1, we identified a monotonic $\tau-\mathrm{V}$ relation, which indicates DNA translocation at all voltages. The cis-to-trans translocation of DNA was verified by PCR amplification of translocated DNA in the trans solution (Figure S6). At the same voltage, $\tau$ was consistently prolonged with lowering trans $\mathrm{pH}$. For example, at $+80 \mathrm{mV}, \tau$ was extended from $0.83 \pm 0.1$ $\mathrm{ms}$ to $1.6 \pm 0.2 \mathrm{~ms}$ as trans $\mathrm{pH}$ was lowered from 3.4 to 2.1 . The $\mathrm{pH}$ effect on $\tau$ suggests that, in addition to voltage, other factors may contribute to translocation deceleration. One of factors could be DNA protonation, which occurs on the $\mathrm{N} 3$ group of adenine $\left(\mathrm{p} K_{\mathrm{a}}=3.5\right)$ and 
cytosine ( $\left.\mathrm{p} K_{\mathrm{a}}=4.2\right)$ (Table $\left.\mathrm{S} 2\right)$. The resulting reduction of the negative charge on DNA (section S2 in the Supporting Information) may assist to slow down translocation.

Deceleration of DNA translocation allows studying how the DNA translocation time is correlated to the DNA length. The Long's group has found that 2-, 3-, 4-, 5-, and 10-base short oligonucleotides can be discriminated in the aerolysin pore based on their characteristic blocking levels, but characterization of longer oligonucleotide translocation remains limited in the neutral environment. We detected the translocation time of targets D5, D16, and D30, which contain 5, 16, and 30 nucleotides, respectively (Table S1), at cis pH 7.4 vs trans $\mathrm{pH} 3.4$ and monitored at $+40 \mathrm{mV}$ (Figure 2). The current traces for the three DNAs show that longer DNA corresponded to longer block duration (Figure 2a). $\tau$ was extended from $0.26 \pm 0.09 \mathrm{~ms}$ for D5, to $2.9 \pm 0.5 \mathrm{~ms}$ for D16, and $4.1 \pm 0.5 \mathrm{~ms}$ for D30 (Figure 2b), suggesting that longer DNA spends longer time to pass through the pore. The translocation speeds for D5, D16, and D30 were about 19, 5.5, and 7.5 bases per millisecond. They are in the same scale but not equal, suggesting that not only the oligonucleotide sequence but also other factors such as the nucleic acids-pore interactions may be involved in the complex translocation procedure. This result indicates the potential for gene fragment length discrimination, which is a long-term interest in our follow-up study.

To understand the remote $\mathrm{pH}$-modulation mechanism, we kept cis $\mathrm{pH}$ at 7.4 and observed the continuous increase of cis DNA capture rate $(+40 \mathrm{mV})$ by lowering trans $\mathrm{pH}$ from 7.4 to 2.1. As shown in Figure 3a,b, the DNA capture rate increased in three phases: Initially, $k_{\text {on }}$ remained zero from trans $\mathrm{pH} 7.4$ to 5.0 and modestly increased up to trans $\mathrm{pH} 3.7$; next, $k_{\text {on }}$ sharply climbed up by tens of fold within a narrow $\mathrm{pH}$ range from 3.7 to 2.6 ; finally, $k_{\mathrm{on}}$ approximated to saturation as trans $\mathrm{pH}$ was continuously lowered. The sharp increase of capture rate corresponds to a $1.5 \mathrm{kcal} \mathrm{mol}^{-1}$ activation energy drop from trans $\mathrm{pH} 4$ to $\mathrm{pH}$ $2.6\left(\mathrm{RT} \ln \left(k_{\mathrm{on}-\mathrm{pH} 2.6} / k_{\mathrm{on}-\mathrm{pH} 4}\right)\right.$. The $\mathrm{k}_{\mathrm{on}}-$ trans $\mathrm{pH}$ correlation can be described using

$$
k_{\text {on }}=k_{\text {on_S }} /\left(1+10^{\text {trans } \mathrm{pH}-\mathrm{pH}_{50}}\right)
$$

where $\mathrm{k}_{\mathrm{On} \_} \mathrm{S}$ is the saturate capture rate, and $\mathrm{pH}_{50}$ is the trans $\mathrm{pH}$ at which $k_{\mathrm{on}}$ is increased to $50 \%$ of $k_{\text {on_s. }}$. The fitting gave $\mathrm{pH}_{50}=3.2$. This trans $\mathrm{pH}$-dependent capture rate is consistent with the $\mathrm{pH}$-dependent protonation probability, which is governed by the Henderson-Hasselbalch equation,

$$
P_{\mathrm{RH}}=1 /\left(1+10^{\mathrm{pH}-\mathrm{p} K_{\mathrm{a}}}\right)
$$

where $\mathrm{P}_{\mathrm{RH}}$ (between 0-1) is the probability of a residue $(\mathrm{R})$ in the protonated state $\left(\mathrm{RH}^{+}\right)$, and $\mathrm{pK}_{\mathrm{a}}$ is the $\mathrm{pH}$ value at which $\mathrm{P}_{\mathrm{RH}}=50 \%$. Comparison of eq 1 and eq 2 suggests that DNA capturing is enhanced by $\mathrm{pH}$-induced protonation. 
To prove the occurrence of protonation, we investigated the ion selectivity of aerolysin, supposing that protonation-induced positive charge on the channel wall can produce a net anion $\left(\mathrm{Cl}^{-}\right)$flow. Indeed, Figure $3 \mathrm{~b}$ shows that the ratio of the $\mathrm{Cl}^{-} \mathrm{vs} \mathrm{K}^{+}$flows through aerolysin dramatically increased from 7 -fold $\left(\mathrm{K}^{+} / \mathrm{Cl}^{-}\right.$permeability ratio $\left.P_{+} / P_{-}=0.14\right)$ in neutral trans solution to 16 -fold $\left(P_{+} / P_{-}=0.06\right)$ at trans pH 3.7, and 50-fold $\left(P_{+} / P_{-}=0.02\right)$ at trans pH 3.2 (Figure S7 for $P_{+} / P_{-}$measurement). Such great enhancement of the net $\mathrm{Cl}^{-}$ flow should be due to the increase of positive charges in the pore, thus verifying the protonation under the $\mathrm{pH}$ gradient. Structurally, the aerolysin pore offers rich protonatable residues on the channel wall and in particular around both entrances (Figure 3c), such as $\mathrm{E} 237, \mathrm{E} 252, \mathrm{E} 254$, and E258 close to the trans entrance for protonation at low trans $\mathrm{pH}$, and D209 and D216 close to the cis entrance for protonation at low cis $\mathrm{pH}$. Their protonation would induce a large number of net positive charges contributed by K238, K242, K244, and K246 in the trans barrel and/or R220, R282, and R288 around the cis entrance, which work together to produce a large net anion flow.

The observed $\mathrm{pH}$-dependent anion flow allows us to propose that there exists a protonationinduced electroosmostic flow that drives DNA capturing by aerolysin. Previously, we have found that engineered $a$-hemolysin pore with different charge polarities can modulate the pore's ion selectivity; the resulting net ion flow produced a nano-electroosmotic flow to drive neutral molecules binding with the pore. In the current study, Figure $3 \mathrm{~b}$ shows that the enhancement of the net $\mathrm{Cl}^{-}$flow was synchronized with the increase of DNA capture rate as trans $\mathrm{pH}$ was lowered. This suggests that the protonation-induced $\mathrm{Cl}^{-}$flow generates a cisto-trans electroosmotic flow at a positive voltage, which can drive DNA into the pore from the cis entrance (Figure 1a model). Similarly, lowering cis pH can result in an opposite trans-to-cis electroosmotic flow under a negative voltage, enabling aerolysin to capture DNA presented in the trans solution (Figure S4 model). The electroosmotic effect is also supported by the observation that the DNA capture rate is linearly increased with the voltage (Figure 1b). This is consistent with the linear voltage-dependence of the electroosmotic flow as determined by the Helmholtz-Smoluchowksi equation and that the capture rate is proportional to the water flow velocity that is increased linearly with the voltage applied.

Figure $3 \mathrm{~b}$ (bottom) also shows that the net $\mathrm{Cl}^{-}$flow reached the maximal level around $\mathrm{pH}$ $3.0\left(J / J_{0}=95 \%\right.$ at trans $\left.\mathrm{pH} 3.2\right)$. Beyond $\mathrm{pH} 3.0$, the electroosmotic effect becomes saturated, but the capture rate continued to increase. One possibility is that very low trans $\mathrm{pH}$ may even "remotely" protonate residues at the cis entrance (e.g., D209 and D216) through a $\left[\mathrm{H}^{+}\right]$gradient across the pore. Upon protonation, the local positively charged residues (e.g., $\mathrm{R} 220, \mathrm{R} 282$, and R288) could attract DNA in the bulk solution. To protonate the cis entrance D209 and D216 ( $K_{\mathrm{a}}=3.86$ ), the trans $\mathrm{pH}$ must be lower than this $\mathrm{p} K_{\mathrm{a}}$ due to a $\mathrm{pH}$ gradient along the pore. This is consistent with the experiment result that the $k_{\mathrm{on}}$-trans $\mathrm{pH}$ curve (Figure $3 \mathrm{~b}$ ) gave $\mathrm{pH}_{50}=3.2$, lower than $\mathrm{p} K_{\mathrm{a}}=3.86$. In addition, we lowered cis $\mathrm{pH}$ to 3.4 (trans $\mathrm{pH}$ remained 7.4) and observed cis DNA capturing blockades (Figure S8), verifying that the protonated cis entrance carrying positive charges can enhance DNA capturing. Moreover, placing charged motif at the protein pore's entrance has been found to enhance DNA capture efficiency and is a key design parameter that needs fulfilling to optimize the biosensing performance. 
In summary, we have discovered a remote $\mathrm{pH}$ modulation mechanism to transform aerolysin into a highly nucleic acids-sensitive nanopore for potential genetic detection. This method is efficient while simple and easy to operate, and the resulting deceleration of DNA translocation is a desired property for both sequencing and precise genetic detection. In addition, this method is also applicable to other nanopore systems (Figure S9). Most importantly, unlike previous work in which $\mathrm{pH}$ of both sides were changed (for $a$ -hemolysin), our method retains the target gene fragments in the neutral environment throughout the detection, therefore effectively preventing target nucleic acids from chemical damaging. In particular, this advantage is critical for preserving the structure of nucleic acids (e.g., RNA tertiary structures). This method may ignite new studies on nanopore sensing mechanism. Guided by the structure, we can engineer the aerolysin pore with different charge distributions to mimic the protonation mechanism and to improve biosensing performance. We can also adapt this method to detection of genetic alteration such as circulating nucleic acids biomarkers ${ }^{-}$and molecular processes like folding and unfolding mechanisms of tertiary nucleic acid structures, and nucleic acids-ligand interactions.

\section{Supplementary Material}

Refer to Web version on PubMed Central for supplementary material.

\section{ACKNOWLEDGMENTS}

We are grateful to the National Institutes of Health for support of this work through Grants GM114204 and HG009338.

\section{REFERENCES}

(1). Howorka S; Siwy Z Chem. Soc. Rev 2009, 38, 2360-84. [PubMed: 19623355]

(2). Kasianowicz JJ; Robertson JW; Chan ER; Reiner JE; Stanford VM Annu. Rev. Anal. Chem 2008, $1,737-66$.

(3). Cherf GM; Lieberman KR; Rashid H; Lam CE; Karplus K; Akeson M Nat. Biotechnol 2012, 30, 344-348. [PubMed: 22334048]

(4). Laszlo AH; Derrington IM; Ross BC; Brinkerhoff H; Adey A; Nova IC; Craig JM; Langford KW; Samson JM; Daza R; Doering K; Shendure J; Gundlach JH Nat. Biotechnol 2014, 32, 829. [PubMed: 24964173]

(5). Rhee M; Burns MA Trends Biotechnol 2006, 24, 580-6. [PubMed: 17055093]

(6). Clarke J; Wu HC; Jayasinghe L; Patel A; Reid S; Bayley H Nat. Nanotechnol 2009, 4, 265-70. [PubMed: 19350039]

(7). Derrington IM; Butler TZ; Collins MD; Manrao E; Pavlenok M; Niederweis M; Gundlach JH Proc. Natl. Acad. Sci. U. S. A 2010, 107, 16060-5. [PubMed: 20798343]

(8). Ying YL; Zhang J; Gao R; Long YT Angew. Chem., Int. Ed 2013, 52, 13154-61.

(9). Wang Y; Tian K; Hunter LL; Ritzo B; Gu L-Q Nanoscale 2014, 6, 11372-11379. [PubMed: 25144935]

(10). Wang Y; Luan B-Q; Yang Z; Zhang X; Ritzo B; Gates K; Gu L-Q Sci. Rep 2015, 4, 5883.

(11). Movileanu L Soft Matter 2008, 4, 925-931.

(12). Bikwemu R; Wolfe AJ; Xing X; Movileanu LJ Phys.: Condens. Matter 2010, 22, 45411.

(13). Rosen CB; Rodriguez-Larrea D; Bayley H Nat. Biotechnol 2014, 32, 179-81. [PubMed: 24441471]

(14). Wolfe AJ; Mohammad MM; Cheley S; Bayley H; Movileanu LJ Am. Chem. Soc 2007, 129, $14034-41$. 
(15). Rotem D; Jayasinghe L; Salichou M; Bayley HJ Am. Chem. Soc 2012, 134, 2781-7.

(16). Wang S; Haque F; Rychahou PG; Evers BM; Guo P ACS Nano 2013, 7, 9814-22. [PubMed: 24152066]

(17). Rodriguez-Larrea D; Bayley H Nat. Nanotechnol 2013, 8, 288-295. [PubMed: 23474543]

(18). Oukhaled G; Mathe J; Biance AL; Bacri L; Betton JM; Lairez D; Pelta J; Auvray L Phys. Rev. Lett 2007, 98, 158101. [PubMed: 17501386]

(19). Goodrich CP; Kirmizialtin S; Huyghues-Despointes BM; Zhu A; Scholtz JM; Makarov DE; Movileanu LJ Phys. Chem. B 2007, 111, 3332-3335.

(20). Mereuta L; Roy M; Asandei A; Lee JK; Park Y; Andricioaei I; Luchian T Sci. Rep 2015, 4, 3885.

(21). Stefureac R; Long YT; Kraatz HB; Howard P; Lee JS Biochemistry 2006, 45, 9172-9. [PubMed: 16866363]

(22). Cressiot B; Braselmann E; Oukhaled A; Elcock AH; Pelta J; Clark PL ACS Nano 2015, 9, 90509061. [PubMed: 26302243]

(23). Pastoriza-Gallego M; Rabah L; Gibrat G; Thiebot B; van der Goot FG; Auvray L; Betton JM; Pelta JJ Am. Chem. Soc 2011, 133, 2923-31.

(24). Payet L; Martinho M. n.; Pastoriza-Gallego M; Betton J-M; Auvray L; Pelta J; Mathe J. r. m. Anal. Chem 2012, 84, 4071-4076. [PubMed: 22486207]

(25). Merstorf C. 1.; Cressiot B; Pastoriza-Gallego M; Oukhaled A; Betton J-M; Auvray L; Pelta J ACS Chem. Biol 2012, 7, 652-658. [PubMed: 22260417]

(26). Stefureac R; Waldner L; Howard P; Lee JS Small 2008, 4, 59-63. [PubMed: 18058890]

(27). Wang Y; Montana V; Grubišić V; Stout RF; Parpura V.; Gu LQ ACS Appl. Mater. Interfaces 2015, 7, 184-192. [PubMed: 25511125]

(28). Fennouri A; Daniel R. g.; Pastoriza-Gallego M; Auvray L; Pelta J; Bacri L Anal. Chem 2013, 85, 8488-8492. [PubMed: 23992452]

(29). Baaken G; Halimeh I; Bacri L; Pelta J; Oukhaled A; Behrends JC ACS Nano 2015, 9, 64436449. [PubMed: 26028280]

(30). Kasianowicz JJ; Brandin E; Branton D; Deamer DW Proc. Natl. Acad. Sci. U. S. A 1996, 93, 13770-3. [PubMed: 8943010]

(31). Wang HY; Li Y; Qin LX; Heyman A; Shoseyov O; Willner I; Long YT; Tian H Chem. Commun. (Cambridge, U. K.) 2013, 49, 1741-3.

(32). Pastoriza-Gallego M; Breton MF; Discala F; Auvray L; Betton JM; Pelta J ACS Nano 2014, 8, 11350-60. [PubMed: 25380310]

(33). Payet L; Martinho M; Merstorf C; Pastoriza-Gallego M; Pelta J; Viasnoff V; Auvray L; Muthukumar M; Mathe J Biophys. J 2015, 109, 1600-7. [PubMed: 26488651]

(34). Cao C; Ying YL; Hu ZL; Liao DF; Tian H; Long YT Nat. Nanotechnol 2016, 11, 713-8. [PubMed: 27111839]

(35). Wang Y; Zheng D; Tan Q; Wang MX; Gu LQ Nat. Nanotechnol 2011, 6, 668-74. [PubMed: 21892163]

(36). Muthukumar MJ Chem. Phys 2010, 132, 195101.

(37). Wanunu M; Morrison W; Rabin Y; Grosberg AY; Meller A Nat. Nanotechnol 2010, 5, 160-165. [PubMed: 20023645]

(38). Rowghanian P; Grosberg AY Phys. Rev. E 2013, 87, 042722.

(39). Squires A; Meller A Biophys. J 2013, 105, 543-4. [PubMed: 23931300]

(40). Tian K; He Z; Wang Y; Chen SJ; Gu LQ ACS Nano 2013, 7, 3962-9. [PubMed: 23550815]

(41). de Zoysa RS; Krishantha DM; Zhao Q; Gupta J; Guan X Electrophoresis 2011, 32, 3034-41. [PubMed: 21997574]

(42). Wang Y; Montana V; Grubisic V; Stout RF, Jr.; Parpura V; Gu LQ ACS Appl. Mater. Interfaces 2015, 7, 184-92. [PubMed: 25511125]

(43). Degiacomi MT; Iacovache I; Pernot L; Chami M; Kudryashev M; Stahlberg H; van der Goot FG; Dal Peraro M Nat. Chem. Biol 2013, 9, 623-9. [PubMed: 23912165]

(44). Iacovache I; De Carlo S; Cirauqui N; Dal Peraro M; van der Goot FG; Zuber B Nat. Commun 2016, 7, 12062. [PubMed: 27405240] 
(45). Gu LQ; Cheley S; Bayley H Proc. Natl. Acad. Sci. U. S. A 2003, 100, 15498-503. [PubMed: 14676320]

(46). Bard AJ, Faulkner LR, Leddy J, Zoski CG Electrochemical Methods: Fundamentals and Applications; Wiley: New York, 1980; Vol. 2.

(47). Maglia G; Restrepo MR; Mikhailova E; Bayley H Proc. Natl. Acad. Sci. U. S. A 2008, 105, 19720-19725. [PubMed: 19060213]

(48). Capone R; Blake S; Restrepo MR; Yang J; Mayer MJ Am. Chem. Soc 2007, 129, 9737-9745.

(49). Calin GA; Croce CM Nat. Rev. Cancer 2006, 6, 857-66. [PubMed: 17060945]

(50). Vlassov VV; Laktionov PP; Rykova EY Curr. Mol. Med 2010, 10, 142-65. [PubMed: 20196731]

(51). Mitchell PS; Parkin RK; Kroh EM; Fritz BR; Wyman SK; Pogosova-Agadjanyan EL; Peterson A; Noteboom J; O’Briant KC; Allen A; Lin DW; Urban N; Drescher CW; Knudsen BS; Stirewalt DL; Gentleman R; Vessella RL; Nelson PS; Martin DB; Tewari M Proc. Natl. Acad. Sci. U. S. A 2008, 105, 10513-8. [PubMed: 18663219]

(52). Zhang X; Xu X; Yang Z; Burcke AJ; Gates KS; Chen SJ; Gu LQ J. Am. Chem. Soc 2015, 137, 15742. [PubMed: 26595106]

(53). Zhang X; Zhang D; Zhao C; Shi R; Burcke AJ; Du X; Chen SJ; Gu LQ Nat. Commun 2017, 8, 1458. [PubMed: 29133841] 


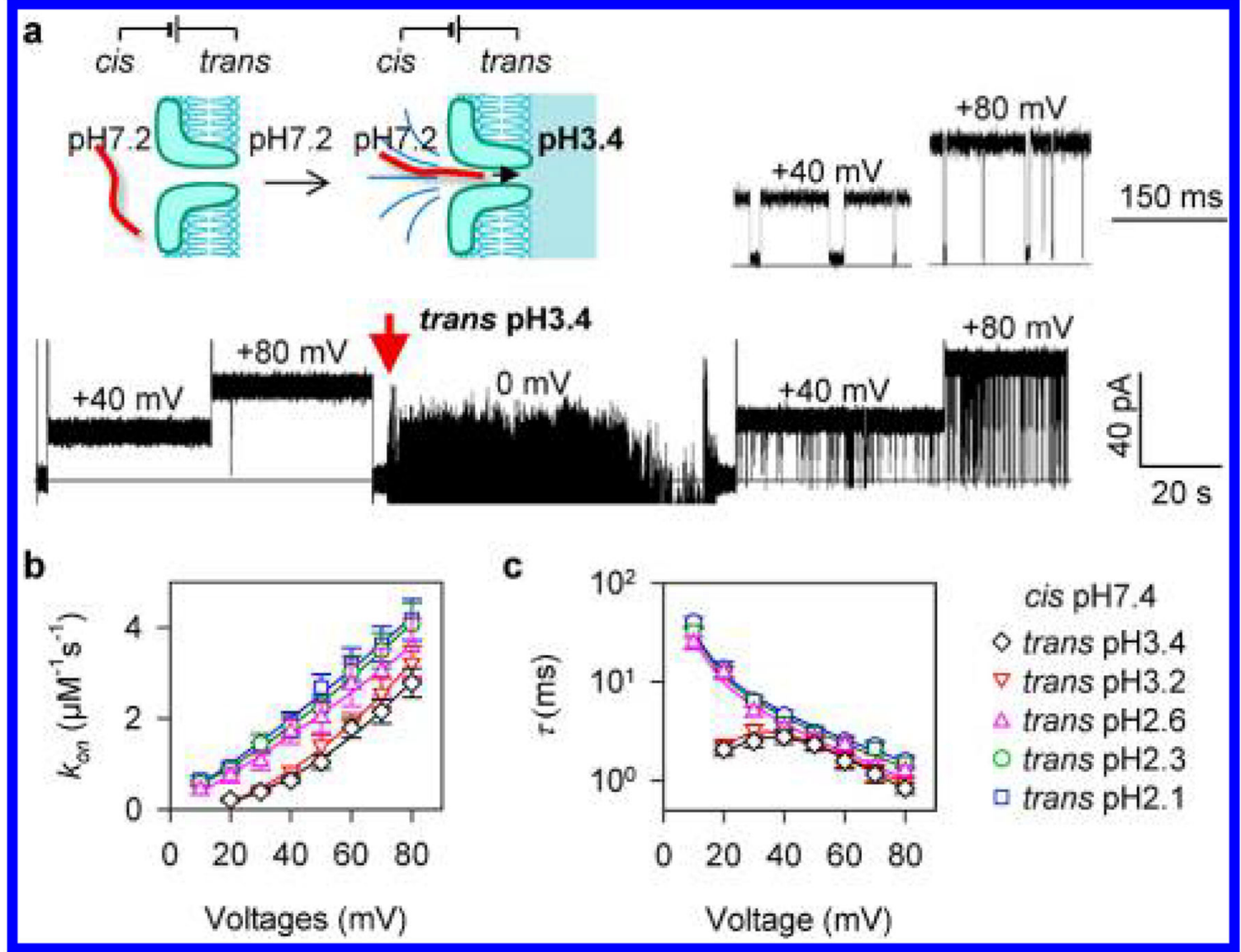

Figure 1.

Activation of aerolysin by acidic solution on one side to capture DNA from the other side capture and translocation. (a) Model (up) and current trace (bottom) showing that DNA D16 $(1 \mu \mathrm{M})$ on the cis side cannot be captured by aerolysin when both cis and trans solutions were at pH 7.4 (left) and can immediately produce a large number of current blocks when trans solution was changed to $\mathrm{pH} 3.4$ while the cis solution remained at $\mathrm{pH} 7.4$ (right). (b and c) Voltage-dependence of DNA capture rate $\left(k_{\mathrm{On}}\right)(\mathrm{b})$ and block duration $(\tau, c)$ at various acidic trans $\mathrm{pH}$ (see Figure S10a-e for histograms). 


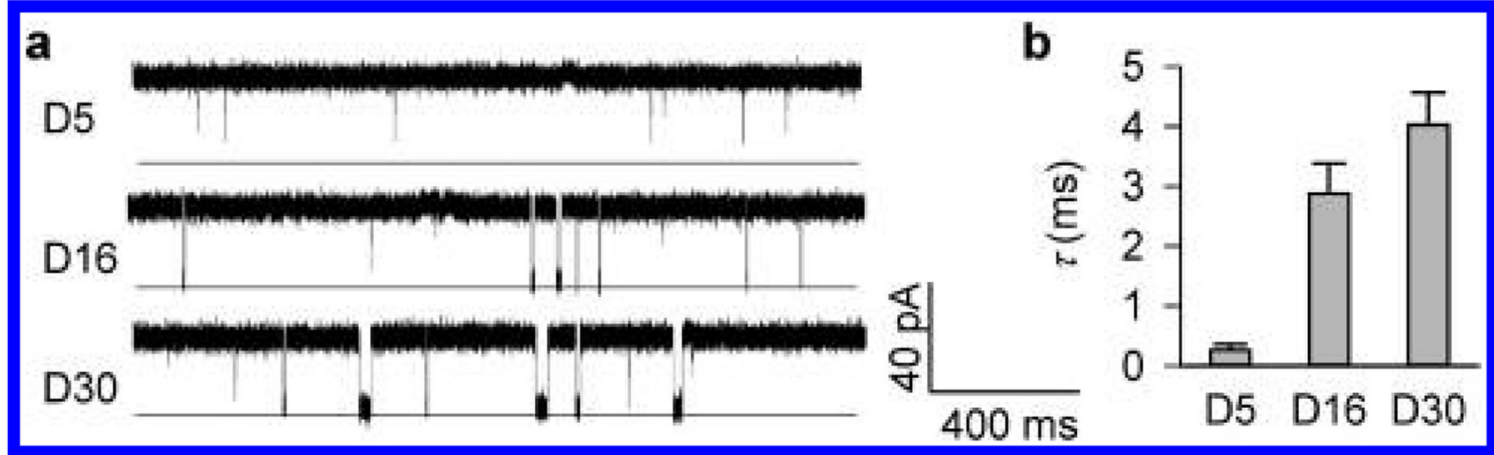

Figure 2.

Discriminating DNA of different lengths from their block durations. (a) Current traces showing DNA blocks in the presence of $1 \mu$ M DNAs D5 (5 nts), D16 (16 nts), and D30 (30 nts) (Table $\mathrm{S} 1$ for sequences) in the cis solution with cis $\mathrm{pH} 7.4$ vs trans $\mathrm{pH} 3.4$, recorded under $+40 \mathrm{mV}$. (b) Duration of blocks by the three different length DNAs. Histograms for $\tau$ are shown in Figure S11. 


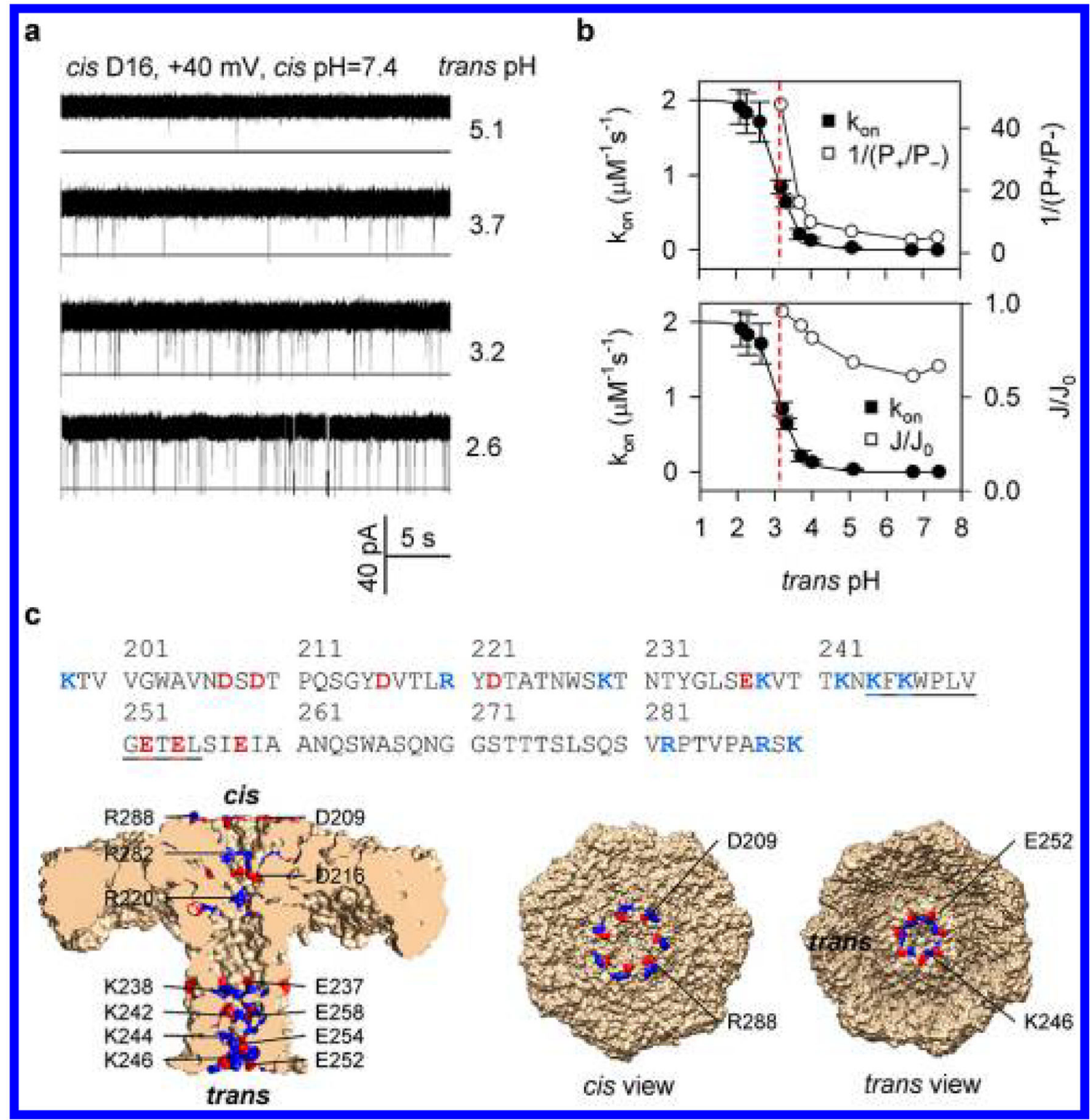

Figure 3.

Trans pH-dependent capture of cis DNA by the aerolysin pore and mechanistic study. (a) Current traces showing the consistent increase of block frequency for the cis DNA D16 (1 $\mu \mathrm{M}$ ) as the trans $\mathrm{pH}$ was lowered from 7.4 to 2.6 (cis $\mathrm{pH}$ remained 7.4). (b) D16 capture rate $\left(k_{\mathrm{on}}\right)$ as the function of the trans $\mathrm{pH}$. The $k_{\mathrm{on}}$-trans $\mathrm{pH}$ curve was fitted using eq 1 . (Top) The trans $\mathrm{pH}$-dependent $\mathrm{K}^{+} / \mathrm{Cl}^{-}$permeability ratio $P_{+} / P_{-}$was shown with the $k_{\mathrm{on}}-\operatorname{trans} \mathrm{pH}$ curve (see Figure S7 for $P_{+} / P_{-}$measurement). (Bottom) trans $\mathrm{pH}$-dependent relative net anion flow $J / J_{0}$ and the $k_{\mathrm{on}}$-trans pH curve. $J=J_{-}-J_{+}$is the net anion flow and $J_{0}$ is the maximal anion flow in which the current is completely carried by anions $\left(J_{0}=J_{-}+J_{+}\right)$. As $P$ ${ }_{+} / P_{-}=J_{+} / J_{-}$, the permeability ratios were transformed into the relative net ion flow as $J / J_{0}=$ $\left(1-P_{+} / P_{-}\right) /\left(1+P_{+} / P_{-}\right)$. (c) Aerolysin structure, including cross-section (left), top view (cis), bottom view (trans), showing charge distribution at the cis and trans entrance. 